\title{
Rival at the gate: first record of the Asian clam Corbicula fluminea Müller, 1774 (Bivalvia: Corbiculidae) in Greece
}

\author{
Ioannis Karaouzas ${ }^{1, *}$, Stamatis Zogaris ${ }^{1}$, Elsa Froufe ${ }^{2}$ and Manuel Lopes-Lima ${ }^{2,3}$ \\ ${ }^{1}$ Institute of Marine Biological Resources \& Inland Waters, Hellenic Centre for Marine Research, 46.7 km Athens-Sounio Av., 19013 \\ Anavyssos, Attica, Greece \\ 2 CIIMAR/CIMAR - Interdisciplinary Centre of Marine and Environmental Research, University of Porto, Rua dos Bragas 289, 4050-123 \\ Porto, Portugal \\ ${ }^{3}$ CIBIO/InBIO - Research Center in Biodiversity and Genetic Resources, University of Porto, Campus Agrário de Vairão, $4485-661$ \\ Vairão, Portugal
}

\begin{abstract}
Received: 28 February 2020 / Accepted: 7 May 2020
Abstract - This contribution presents the first record of the Asian clam Corbicula fluminea Müller, 1774 in Greece. The species was collected in Erythropotamos River (Reka Luda Луда река), one of the main tributaries of Evros River (classical name of the Maritsa river), thus being the southernmost record of this invasive bivalve in the Balkan Peninsula. The most likely entry source of $C$. fluminea in Greece is through active or passive downstream drift through the Bulgarian part of Erythropotamos River, which is shared between Bulgaria and Greece. Special attention is now required to assess the invasion extent of the Asian clam in the entire Evros basin and adjacent river basins of Bulgaria and the Aegean basins of Greece and Turkey.
\end{abstract}

\begin{abstract}
Keywords: Invasive / alien species / bioinvasion / dispersion / freshwater
Résumé - Rival à la porte : Première mention de la palourde asiatique Corbicula fluminea Müller, 1774 (Bivalvia : Corbiculidae) en Grèce. Cette contribution présente le premier signalement de la palourde asiatique Corbicula fluminea Müller, 1774 en Grèce. L'espèce a été récoltée dans la rivière Erythropotamos (Reka Luda Луда река), l'un des principaux affluents de l'Evros (nom classique de la rivière Maritsa), constituant ainsi la mention la plus méridionale de ce bivalve envahissant dans la péninsule balkanique. La source d'entrée la plus probable de $C$. Aluminea en Grèce est la dérive active ou passive vers l'aval de la partie bulgare de l'Erythropotamos, que se partagent la Bulgarie et la Grèce. Une attention particulière est maintenant nécessaire pour évaluer l'étendue de l'invasion de la palourde asiatique dans tout le bassin de l'Evros et les bassins fluviaux adjacents de Bulgarie et les bassins de la mer Égée de Grèce et de Turquie.
\end{abstract}

Mots clés : invasion / espèces exotiques / bioinvasion / dispersion / eau douce

The Asian clam Corbicula fluminea Müller, 1774 is regarded as one of the most persistent invasive species in freshwater ecosystems, due to its great potential for dispersion and nuisance characteristics responsible for high ecological and economic impacts (Sousa et al., 2008a, 2008b). It can dominate macroinvertebrate communities, physically alter benthic habitats, and disrupt regulating ecosystem services (Sousa et al., 2008b, 2014). Despite policy and management efforts to reduce invader spread, $C$. fluminea continues to spread across freshwater systems (Caffrey et al., 2016). The rapid growth, high fecundity, early sexual maturity, short life span, and its association with human activities make

\footnotetext{
*Corresponding author: ikarz@hcmr.gr
}

C. fluminea a non-indigenous invasive species likely to colonize new environments (Sousa et al., 2008a). It has undergone a massive global range expansion since the 1940s, spreading from its native range in Southeast Asia, to North, Central and South America, and then to Europe (Crespo et al., 2015).

C. fluminea has spread to most European rivers including the Rhine, Garonne, Loire, Seine, and Rhone (Marescaux et al., 2010) and in the entire Danube Basin (e.g. Csányi, 1999; Bij de Vaate and Hulea, 2000). It has also spread to river basins in the Iberian and Italian Peninsula (Cianfanelli et al., 2007; Pérez-Quintero, 2008) and in hydrologically unconnected watersheds including the UK (Elliott and zu Ermgassen, 2008) and Ireland, where it was recorded for the first time in 2010 (Lucy et al., 2012). Expansion of invasive range and 


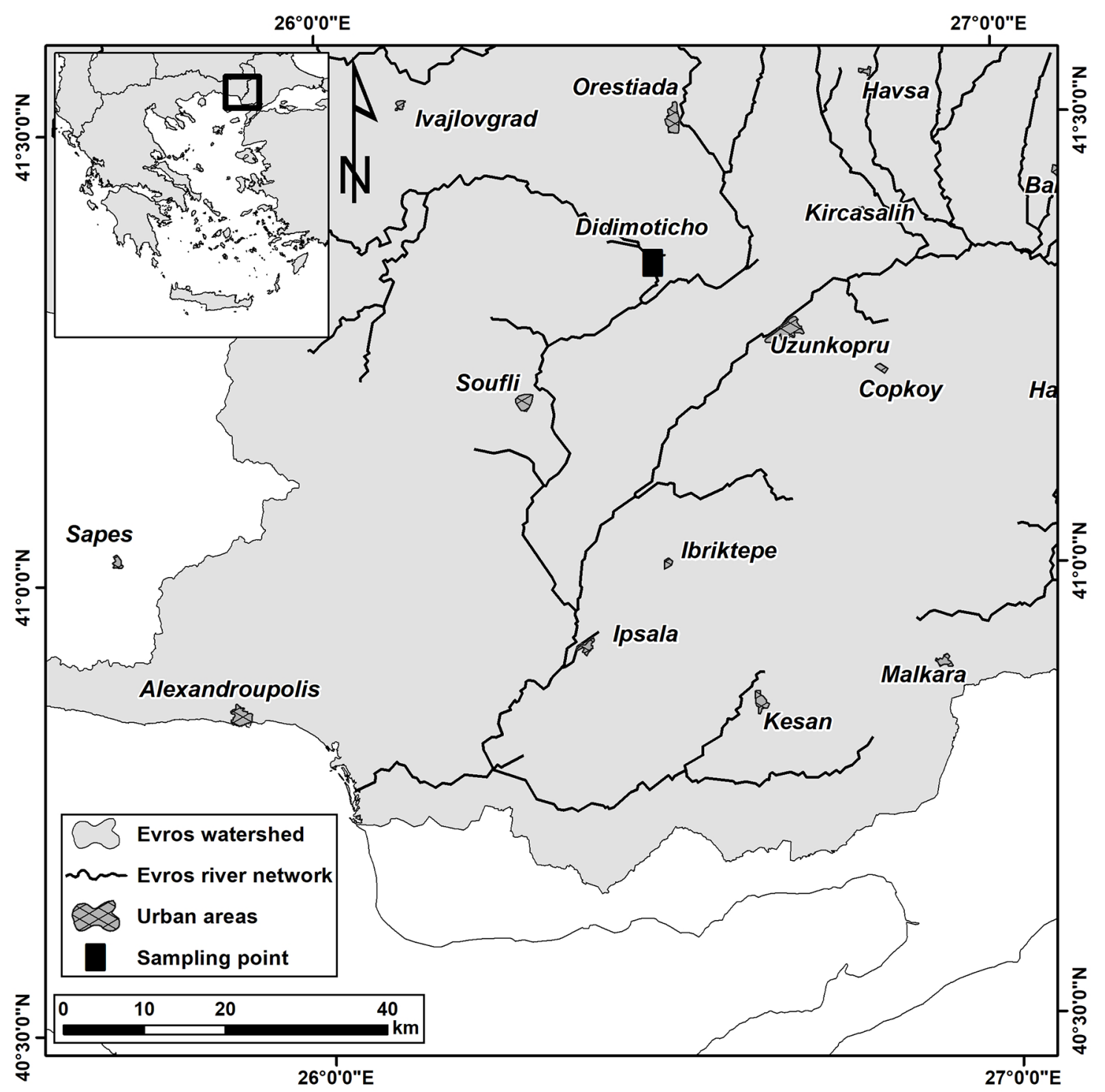

Fig. 1. Map showing the sampling site of Corbicula fluminea.

flourishing populations are also recently reported in Poland (e.g. Oder river; Cebulska and Krodkiewska, 2019) and western Turkey (Serdar, 2018).

In this contribution, $C$. fluminea is reported for the first time in Greece, being the southernmost record of the species in the Balkan Peninsula. The Asian clam was found in the Evros River Basin, the second largest river in southeastern Europe (after the Danube), and the main river in the Balkan Peninsula, with a total length of about $530 \mathrm{~km}$ and a drainage area of $53,000 \mathrm{~km}^{2}$. This transboundary river is shared among Bulgaria, Turkey, and Greece.

On the 8th of September 2018, 12 individuals of C. fluminea were found during a routine EU Water Framework Directive monitoring in the lower part of the Erythropotamos river, only $2.5 \mathrm{~km}$ from its confluence with the main-stem of the Evros river (Fig. 1); specimens were photographed alive on-site and re-released into the water. Benthic conditions are dominated by silt, and there are also gravel and sandy substrates with some woody debris. Margins are rich in aquatic macrophytes (including floating plants, such as Trapa natans) and fringed with helophytes (e.g. Sparganium sp., Typha sp.). The sampled site is rich in fish; 17 species have been recorded in recent years. Due to low river waters creating exposed river beds, the living clams were incidentally located in the shallows. Physicochemical parameters of the sampling location were measured with a GPS Aquameter from Aquaread Ltd.

Due to the taxonomic uncertainties involving the Corbicula genus, the identity of the species was verified by genetic analysis. Whole genomic DNA was extracted from small tissue pieces preserved in $96 \%$ ethanol, using a standard high-salt protocol (Sambrook et al., 1989), from 2 individuals. A fragment of the cytochrome oxidase c subunit I gene (COI) was amplified by PCR using universal primer modified versions, i.e., LCO22me2 and HCO700dy2 (Walker et al., 2006, 2007). PCR conditions are described in Froufe et al. (2014) with an annealing temperature of $48^{\circ} \mathrm{C}$. Amplified DNA templates were purified and sequenced (forward and reverse) by the commercial company Macrogen, using the same primers. The sequences obtained were compared with 
Table 1. Physicochemical parameters and habitat characteristics of C. fluminea collection site.

\begin{tabular}{|c|c|}
\hline \multicolumn{2}{|l|}{ PARAMETERS (Units) } \\
\hline \multicolumn{2}{|l|}{$\begin{array}{l}\text { PARAMETERS (Units) } \\
\mathrm{nH}\end{array}$} \\
\hline Water temperature $\left({ }^{\circ} \mathrm{C}\right)$ & 24.15 \\
\hline Conductivity $(\mu \mathrm{S} / \mathrm{cm})$ & 793 \\
\hline TDS $(\mathrm{mg} / \mathrm{l})$ & 397 \\
\hline Salinity (ppt) & 0.39 \\
\hline Turbitity (NTU) & 14.9 \\
\hline D.O. $(\%)$ & 158.46 \\
\hline D.O. $(\mathrm{mg} / \mathrm{l})$ & 13.35 \\
\hline $\mathrm{BOD}(\mathrm{mg} / \mathrm{l})$ & 20.5 \\
\hline $\mathrm{Cl}(\mathrm{mg} / \mathrm{l})$ & 83.83 \\
\hline $\mathrm{Si}(\mathrm{mg} / 1)$ & 5 \\
\hline $\mathrm{N}-\mathrm{NO}_{2}(\mathrm{mg} / \mathrm{l})$ & 0.078 \\
\hline $\mathrm{N}-\mathrm{NO}_{3}(\mathrm{mg} / \mathrm{l})$ & 4.372 \\
\hline $\mathrm{N}-\mathrm{NH}_{4}(\mathrm{mg} / \mathrm{l})$ & 0.024 \\
\hline $\mathrm{DIN}(\mathrm{mg} / \mathrm{l})$ & 4.474 \\
\hline $\mathrm{TN}(\mathrm{mg} / \mathrm{l})$ & 4.692 \\
\hline $\mathrm{P}-\mathrm{PO}_{4}(\mathrm{mg} / \mathrm{l})$ & 0.005 \\
\hline $\mathrm{TP}(\mathrm{mg} / \mathrm{l})$ & 0.014 \\
\hline Mud $(0.0625-2 \mathrm{~mm})(\%)$ & 50 \\
\hline Silt \& Clay $(<0.0625 \mathrm{~mm})(\%)$ & 50 \\
\hline Aquatic vegetation (\%) & 30 \\
\hline Canopy cover (\%) & 20 \\
\hline Air temperature $\left({ }^{\circ} \mathrm{C}\right)$ & 30 \\
\hline Physicochemical quality & Good \\
\hline
\end{tabular}

sequences present in GenBank using BLAST (Altschup et al., 1990) and with the BOLD database (Ratnasingham and Hebert, 2007). No indels and no stop codons were observed, after translating all sequences to amino acids. The identification of the newly sequenced individuals (a single haplotype: GenBank SUBMITTED) as C. fluminea was confirmed by both BOLD (99.8\% match) and BLAST (99.6\%).

The physicochemical characteristics of sampling locality are presented in Table 1. Overall, the physicochemical quality of the sampling site was good, as classified according to the physicochemical quality index (Skoulikidis et al., 2006); however, fish-based assessments of the lower Erythropotamos water body have indicated moderate to poor conditions in recent years, mainly due to degradation from water abstraction, hydromorphological changes and seasonal eutrophic conditions that affect natural fish assemblages (Zogaris et al., 2018). Although the potential use of Corbicula species for biomonitoring purposes has been suggested (e.g. Doherty, 1990), C. fluminea is considered generally intolerant to severe pollution (e.g. Ilarri et al., 2010). Europe's Directives on improving ecological quality may have facilitated invasion by providing better environmental conditions for all life stages of C. Aluminea (Karatayev et al., 2007) as this seems to be correlated with the reinvasion of zebra mussel in some European rivers (Jantz and Neumann, 1992) and other invasive species in the Laurentian Great Lakes of North America (Mills et al., 2003).

In most cases dealing with biological invasions, it is very difficult to trace the introduction vectors and pathways and the subsequent dispersion. In Europe for example, inland waterway connectivity facilitates the spread of invasive nonautochthonous species (Leuven et al., 2009; Panov et al., 2009). European floodplains (i.e. low altitude rivers) are the main corridor routes consisting of an interlinked network of 30 main canals with more than 100 branches, and more than 350 ports (Panov et al., 2009; Galil et al., 2008). An increasing number of dams have also facilitated many lentic alien and translocated species (Koutsikos et al., 2019) and large river systems such as the Evros have experienced recent developments, particularly in the Evros river basin's Bulgarian section.

We speculate that $C$. fluminea reached the Greek waters of Erythropotamos river most possibly through passive downstream transport from Bulgaria. The Evros river basin has been called an "open-door" for invasive alien biota (Ozulug et al., 2018). This refers to human-assisted aquatic species dispersal which disperses downstream of Bulgarian entry points. In this way, the north-south running Evros and its tributaries such as the Erythropotamos, are pathway gates for species entering the Aegean basins of Greece and Turkey from Bulgaria's Danubian and Black Sea basin invasive alien biota (Zogaris et al., 2019). In recent years this transport could have been either facilitated by human activities, such as increased hydroelectric dam-building, fishing and various recreational activities or by bird transfer (Crespo et al., 2015; Coughlan et al., 2017) or naturally by downstream drift. C. fluminea has found to be capable of floating after being exposed to gentle water currents produced by an aquarium filtration system (current speeds, 10 to $20 \mathrm{~cm} / \mathrm{sec}$; Prezant and Chalermwat, 1984). The first record of $C$. Aluminea in Bulgaria was from the Danube River at Vetren in 2001 and after 11 years the species has occupied the entire Bulgarian stretch of the Danube, from Vrav to Vetren, where it reached densities up to $16,560 \mathrm{ind} / \mathrm{m}^{2}$ (Hubenov et al., 2013). Recently, the species was also found in lentic waters, two reservoirs and one sand-pit lake, located at altitudes of up to $525 \mathrm{~m}$ a.s.l. (Hubenov et al., 2013). Based on the Bulgarian invasion experience with the species, it is anticipated that the entire Evros River Basin is or soon will be occupied by the clam. Thus, more detailed surveillance is urgently needed in order to assess the degree of C. fluminea establishment in the basin and adjacent freshwater bodies.

Acknowledgements. This contribution represents incidental observations and collections made during the National Water Framework Directive monitoring project funded by the Ministry of Environment and Energy and by the European Union. We thank D. Kommatas and the boat-based electrofishing unit for assistance in field work, Dr. E. Dimitriou scientific coordinator of the project and the two anonymous for their valuable comments.

\section{References}

Altschup SF, Gish W, Miller W, Myers EW, Lipman DJ. 1990. Basic local alignment search tool. J Mol Biol 215: 403-410.

Bij de Vaate A, Hulea O. 2000. Range extension of the Asiatic clam Corbicula fluminea (Müller 1774) in the River Danube: first record from Romania. Lauterbornia 38: 23-26.

Caffrey JM, Dick JTA, Lucy FE, Davis E, Niven A, Coughlan NE. 2016. First record of the Asian clam Corbicula fluminea (Müller, 
1774) (Bivalvia, Cyrenidae) in Northern Ireland. BioInvasions Rec 5: 239-244.

Cebulska KD, Krodkiewska M. 2019. Further dispersion of the invasive alien species Corbicula fluminea (OF Müller, 1774) in the Oder River. Knowl Manag Aquat Ecosyst 420: 14.

Cianfanelli S, Lori E, Bodon M. 2007. Non-indigenous freshwater molluscs and their distribution in Italy. In: Gherardi F, ed. Biological invaders in inland waters: profiles, distribution, and threats. Invading Nature. Springer Series in Invasion Ecology, Springer, Dordrecht, The Netherlands, 103-121.

Coughlan NE, Stevens AL, Kelly TC, Dick JTA, Jansen MAK. 2017. Zoochorous dispersal of freshwater bivalves: an overlooked vector in biological invasions? Knowl Manag Aquat Ecosyst 418: 42.

Crespo D, Dolbeth M, Leston S, Sousa R, Pardal MÂA. 2015. Distribution of Corbicula fluminea (Müller, 1774) in the invaded range: a geographic approach with notes on species traits variability. Biol Invasions 17: 2087-2101.

Csányi B. 1999. Spreading invaders along the Danubian highway: first record of Corbicula fluminea (O.F. Müller 1774) and C. fluminalis (O.F. Müller 1774) in Hungary (Mollusca: Bivalvia). Folia Hist Nat Mu Matra 23: 343-345.

Doherty FG. 1990. The Asiatic clam, Corbicula spp., as a biological monitor in freshwater environments. Environ Monit Assess 15: $143-181$.

Elliott P, zu Ermgassen PS. 2008. The Asian clam (Corbicula fluminea) in the River Thames, London, England. Aquat Invasions 3: $54-60$.

Galil BS, Nehring S, Panov V. 2008. Waterways as invasion highways - impact of climate change and globalization. In: Nentwig W. ed. Biological Invasions. Ecological Studies (Analysis and Synthesis), vol. 193. Springer, Berlin, Heidelberg, 59-74.

Jantz B, Neumann D. 1992. Shell growth and aspects of the population dynamics of Dreissena polymorpha in the River Rhine. The zebra mussel Dreissena polymorpha. Ecology, biology monitoring and first applications in the water quality management. New York: Gustav Fisher, 49-66.

Hubenov Z, Trichkova T, Kenderov L, Kozuharov D. 2013. Distribution of Corbicula fluminea (Mollusca: Corbiculidae) over an eleven-year period of its invasion in Bulgaria. Acta zool bulg 65: 315-326.

Ilarri MI, Antunes C, Guilhermino L, Sousa R. 2010. Massive mortality of the Asian clam Corbicula fluminea in a highly invaded area. Biol Invasions 13: 277-280.

Karatayev AY, Padilla DK, Minchin D, Boltovskoy D, Burlakova LE. 2007. Changes in global economies and trade: the potential spread of exotic freshwater bivalves. Biol Invasions 9: 161-180.

Koutsikos N, Zogaris S, Vardakas L, Kalantzi O, Dimitriou E, Economou A. 2019. Tracking non-indigenous fishes in lotic ecosystems: Invasive patterns at different spatial scales in Greece. Sci Total Environ 659: 384-400.

Leuven RS, van der Velde G, Baijens I, Snijders J, van der Zwart C, Lenders HR, Bij de Vaate A. 2009. The river Rhine: a global highway for dispersal of aquatic invasive species. Biol invasions 11: 1989-2008.

Lucy F, Karatayev A, Burlakova L. 2012. Predictions for the spread, population density and impacts of Corbicula fluminea in Ireland. Aquat Invasions 7: 465-474.
Marescaux J, Pigneur LM, Van Doninck K. 2010. New records of Corbicula clams in French rivers. Aquat Invasions 5(Suppl 1): S35-S39.

Ozulug M, Gaygusuz O, Gaygusuz CG, Sac G. 2018. New distribution areas of four invasive freshwater fish species from Turkish Thrace. Turk J Fish Aquat Sci 19: 837-845.

Sambrook J, Fritsch EF, Maniatis T. 1989. Molecular Cloning: A Laboratory Manual, 2nd edn. Cold Spring Harbor, NY: Cold Spring Harbor Laboratory Press.

Skoulikidis N, Amaxidis Y, Bertahas I, Laschou S, Gritzalis K. 2006. Analysis of factors driving stream water composition and synthesis of management tools - a case study on small/medium Greek catchments. Sci Total Envir 362: 205-241.

Sousa R, Antunes C, Guilhermino L. 2008a. Ecology of the invasive Asian clam Corbicula fluminea (Müller, 1774) in aquatic ecosystems: An overview. Ann Limnol - Int J Lim 44: 85-94.

Sousa R, Nogueira AJA, Gaspar M, Antunes C, Guilhermino L. $2008 \mathrm{~b}$. Growth and extremely high production of the nonindigenous invasive species Corbicula fluminea (Muller, 1774): possible implications for ecosystem functioning. Estuar Coast Shelf Sci 80: 289-295.

Sousa R, Novais A, Costa R, Strayer DL. 2014. Invasive bivalves in fresh waters: impacts from individuals to ecosystems and possible control strategies. Hydrobiologia 735: 233-251.

Panov VE, Alexandrov B, Arbaciauskas K, Binimelis R, Copp GH, Grabowski M, Lucy F, Leuven RSEW, Nehring S, Paunovic M, Semenchenko V, Son MO. 2009. Assessing the risks of aquatic species invasions via European inland waterways: from concepts to environmental indicators. Integr Environ Assess Manag 5: $110-126$.

Pérez-Quintero JC. 2008. Revision of the distribution of Corbicula fluminea (Müller, 1744) in the Iberian Peninsula. Aquat Invasions 3: 355-358.

Prezant RS, Chalermwat K. 1984. Flotation of the bivalve Corbicula fluminea as a means of dispersal. Science 225: 1491-1493.

Ratnasingham S, Hebert PDN. 2007. BOLD: the barcode of life data system (www.barcodinglife.org). Mol Ecol Notes 7: 355-364.

Serdar S. 2018. Growth of the Asian Clam Corbicula fluminea (Müller, 1774) Cultured in Çine Creek, Aydin, Turkey. J Shellfish Res 37: 491-496.

Walker JM, Curole JP, Wade DE, Chapman EG, Bogan AE, Watters GT, Hoeh WR. 2006. Taxonomic distribution and phylogenetic utility of gender-associated mitochondrial genomes in the Unionoida (Bivalvia). Malacologia 48: 265-282.

Walker JM, Bogan AE, Bonfiglio EA, Campbell DC, Christian AD, Curole JP, Harris JL, Wojtecki RJ, Hoeh WR. 2007. Primers for amplifying the hypervariable, male-transmitted COII-COI junction region in amblemine freshwater mussels (Bivalvia: Unionoidea: Ambleminae). Mol Ecol Notes 7: 489-491.

Zogaris S, Tachos V, Economou AN, Chatzinikolaou Y, Koutsikos N, Schmutz S. 2018. A model-based fish bioassessment index for Eastern Mediterranean rivers: Application in a biogeographically diverse area. Sci Total Environ 622: 676-689.

Zogaris S, Ntakis A, Barbieri R. 2019. The Racer Goby, Babka gymnotrachelus (Kessler, 1857) invades the Evros River: Evidence of recent establishment in Greece. Knowl Manag Aquat Ecol 420: 13.

Cite this article as: Karaouzas I, Zogaris S, Froufe E, Lopes-Lima M. 2020. Rival at the gate: first record of the Asian clam Corbicula fluminea Müller, 1774 (Bivalvia: Corbiculidae) in Greece. Knowl. Manag. Aquat. Ecosyst., 421, 24. 